\title{
6
}

\section{Clothing the Emperor: Supporting National Climate Change Action in Ireland Through Local Governance Networks}

\section{Glen Smith}

\section{Introduction}

'The Emperor has no clothes.' (Saoi O'Connor, Cork city school climate striker)

Saoi O'Connor was one of the first school strikers for climate in the city of Cork, Ireland. Every Friday during 2019, she would sit outside Cork City Hall with a sign that expressed her outrage at the way adults were responding to the climate crisis. At the age of sixteen, she took the decision to stop attending regular school and commit to home schooling and organising actions for the fight against climate change. Saoi went on to address the Fridays for Future press conference at the United Nations Climate Change Conference (COP25) in Madrid. Here, she claimed that

\footnotetext{
G. Smith (凶)

Middlesex University, London, UK

e-mail: g.smith@mdx.ac.uk 
the language of climate change talks, especially at the United Nations (UN) level, was kept deliberately technical and heavy on the use of jargon in order to keep the general public from fully understanding the content. Saoi's protest sign from the streets of Cork is not heavy on the use of jargon. It reads 'The Emperor has no clothes', a slogan inspired by Hans Christian Andersen's tale The Emperor's New Clothes (Andersen, 1949). The Emperor in this case is the Irish Government. Saoi is suggesting that the Irish Government's strategy for tackling the climate crisis does not go far enough. Policies upon policies and reports upon reports are doing an increasingly poor job of concealing a lack of action. Some might deem this an overly harsh criticism, but the slogan does invite us to explore how Ireland is responding to the climate crisis, and if there is room for improvement.

The fight against climate change (referred to in this chapter as 'climate action') underpins the survival of socio-ecological (human-nature) systems. Climate change impacts - rising sea levels, more frequent and intense storms, floods, droughts and extreme cold and hot temperature shocks - are indeed an existential threat (Kjellstrom \& McMichael, 2013; Thuiller et al., 2005). Climate action seeks to counteract this threat through both mitigation and adaptation measures. Mitigation involves addressing the causes of climate change, most notably by reducing greenhouse gas emissions. Mitigation efforts are essential, but we are witnessing the impacts of climate change on a more regular basis and must begin to adapt to these. Adaptation measures are designed to make our systems, infrastructures and behaviours more resilient to climate change impacts.

Climate action is also intricately interwoven with disaster risk reduction (DRR) and the Sustainable Development Goals (SDGs). For example, the infrastructure needed to supply farmers, process and transport the harvest, and manufacture and distribute consumables to customer sale points needs to remain free of disruption. Storms and droughts can disrupt this process at multiple points. Should the chain be broken, the livelihoods of food producers can be seriously affected, as can wider food security. Vulnerabilities in food production chains undermine our attempts to achieve the goal of zero hunger (SDG2). Conversely, an educated society that is free of poverty and hunger can potentially commit more time and energy to climate action. Similar causal links can be 
drawn between all of the SDGs. A recent report by the World Economic Forum clearly maps out the systemic connections between failing climate action and food crises, biodiversity losses, involuntary migration, water crises and a host of other global risks (WEF, 2020). These processes do not only affect the Global South; they also affect countries such as Ireland.

Efforts are ongoing in Ireland to integrate these three policy areas. The Irish Government contributed to the Sendai Framework for Disaster Risk Reduction 2015-2030 and produced a Sustainable Development Goals National Implementation Plan for 2018-2020. There is also clarity on how these actions should be governed. For example, the Minister for Communications, Climate Action and the Environment has overall responsibility for promoting the SDGs in Ireland. For each SDG target, the lead and stakeholder government departments will be named, with the list constantly updated. A number of 'SDG champions' have also been named, which are national organisations who can leverage appropriate action. The list is diverse and includes An Post (the postal service), Vodafone and the Irish Congress of Trade Unions.

Robust and flexible governance systems are essential for implementing policy and, where necessary, changing policy. This chapter considers the governance of climate action in Ireland, the next section provides some relevant governance theory, and the subsequent two sections outline Ireland's climate change policy and how its implementation is governed respectively. The town of Youghal, County Cork is then presented as a useful case study of local governance processes. The chapter concludes with ideas for how the emperor might be clothed.

\section{Governance: Theoretical Concepts}

A governance system helps organise people and their actions. These actions can be understood as the management tools that affect a system. Norway's series of financial incentives for purchasing and running electric cars is an example of a management tool to support climate change mitigation. A procedure for the assessment of the structural integrity of roads and buildings after extreme weather events is an example of a 
climate change adaptation (CCA) management tool. Governance, on the other hand, is the process of organising people around these tools. A governance system helps determine how these processes are designed, who oversees them and how they might be changed, improved or discarded. Patsy Healey (2003) describes governance as 'the processes by which societies, and social groups, manage their collective affairs' (p. 104). In short, governance manages the rules of the game (Kjaer, 2004).

According to governance theory, governing is not something done exclusively by those at the top of a hierarchical system. It can happen at various levels and in formal and informal settings. In fact, it can be said that the 'new political culture no longer places much faith in solutions imposed from above, increasingly relying instead on a network of decision-making relationships that link government and civil society across many scales' (Van Driesche \& Lane, 2002: 283). As a result, 'changes have taken place in the forms and mechanisms of governance, the location of governance, governing capacities and styles of governance' (Kersbergen \& Waarden, 2004: 143). Governance is a process of continual negotiation. This continual negotiation occurs in a polycentric system (Morrison et al., 2017). Polycentric governance systems are multi-scalar and made up of many autonomous units which take account of one another through mutual adjustment.

These descriptions of modern governance invite us to engage with questions of power. Who has a say in management processes? Who is marginalised, either through design or unintentionally? How does this occur? This is often a question of incentives. Incentives are central to our (in)action on climate change. For example, Saffron O'Neill and Sophie Nicholson-Cole have demonstrated how the fear generated by the media around climate change might be useful for attracting people's attention, but it is ineffective for driving changes in personal behaviour (O'Neill \& Nicholson-Cole, 2009). In fact, hope has been proven to be a more powerful incentive (Nabi et al., 2018). However, incentives also play a key role on a systemic level, beyond the behaviour of the individual. The incentives of powerful actors can shape policy direction or determine actions that continue in spite of that policy (Clarke \& Flannery, 2020; Smith \& Jentoft, 2017; Tafon, 2018). To achieve transformational change, 'we need to ensure that the impact drivers working towards such 
a change are stronger than the impact drivers that cause climate change' (Uitto et al., 2017: 31). This requires effort 'outside of climate change action' (Ibid.) to actively dissuade non-sustainable natural resource use.

\section{The Emperor's Clothes}

Since 2015, Ireland has accelerated its progress towards delivering comprehensive climate change policy. The Climate Action and Low Carbon Development Act 2015 paved the way for a series of policies aimed to support both mitigation and adaptation actions. The main policies relevant to climate change include:

- The National Planning Framework (Project Ireland 2040) (DHPLG, 2018)

- The National Mitigation Plan (NMP) (DCCAE, 2017)

- The National Adaptation Framework (NAF) (DCCAE, 2018)

- The Climate Action Plan (CAP) (DCCAE, 2019)

- Twelve Sectoral Adaptation Plans

- Local Authority Climate Change Adaptation (CCA) Strategies

Ireland is beginning to introduce more climate change adaptation measures in addition to mitigation efforts, following the global trend to do so (Di Gregorio et al., 2017; Thornton \& Comberti, 2017). The Government has stated that 'sufficient robust information now exists nationally to further progress the process of implementing adaptation actions and increasing social, economic and environmental resilience to climate change' (DCCAE, 2018). The policies listed above contain a wide range of actions and objectives that outline exactly how the nation can incorporate climate change thinking into the way it builds, travels, consumes, works and relaxes. The CAP alone contains 183 actions spread over the areas of the current state of play, governance, carbon pricing, electricity, enterprise, the built environment, transport, agriculture, forestry and land use, waste and the circular economy, the public sector leading by example, citizen engagement, community leadership and just transition, and adaptation. An 'all-of-government' approach helps ensure 
that climate change is taken seriously in all government departments (DCCAE, 2019). The sectoral plans and local authority strategies do the same for all industries and lower administrative levels.

The example of transport infrastructure helps demonstrate how climate actions cascade through the various administrative levels in Ireland. The National Planning Framework (Ireland 2040) defines its National Strategic Outcome 2: Enhanced Regional Accessibility as:

Enabling more effective traffic management within and around cities and re-allocation of inner-city road-space in favour of bus-based public transport services and walking/cycling facilities. (DHPLG, 2018: 140)

So, from a planning perspective, it appears that more emphasis will be based in future on transitioning away from car-use in urban areas towards alternative modes of transport, including buses. The National Development Plan (2018-2027) adds a stronger climate change element by outlining the following investment action:

Transition to low emission buses, including electric buses, for the urban public bus fleet, with no diesel-only buses purchased from July 2019, while promoting commercial bus services and small public service vehicle industry to pursue low emission fleet. (Irish-Government, 2018: 54)

Continuing with this theme, the CAP includes in Action 87 (abridged):

All future procurement processes for public buses will include evaluation of procuring only fully electric buses. This evaluation will include review of how electric buses have been introduced into other cities in a cost-effective way, including London, Paris and Manchester. (DCCAE, 2019: 96)

From the Ireland 2040 ambition to provide more effective traffic management, we now see the addition of greener choices. Not only should more bus travel options be provided but these should, where possible, involve only fully electric buses. The Transport Sectoral Climate Change Adaptation Plan integrates relevant actions into the transport sector. This policy marks a departure from pure mitigation thinking (such as introducing electric bus fleets) and explores how the infrastructure might be 
kept running during system shocks, such as 'acute weather events', which constitutes adaptation. For example, Action 16 states:

Continue engagement with disaster risk management for transport through active participation with the Office for Emergency Planning and the National Directorate for Fire and Emergency Management to ensure operational continuity and service delivery during acute weather events. (DTTS, 2019: 89)

Action 21 also states:

Support implementation of remote working initiatives, including expansion of effective broadband connectivity, to facilitate remote working when travel is inhibited during extreme weather events. (DTTS, 2019: 90)

Whilst these actions would extend beyond bus services, they are clear examples of adaptation measures whereby steps are taken to ensure that a service either continues to operate under abnormal conditions or that users have alternative options. The Irish Transport Sectoral Climate Change Adaptation Plan is also relatively advanced in considering links to the SDGs. Under 'Related UN SDGs' for Action 16, for example, it lists numbers 3, 6, 7, 8, 9, 11, 13, 14 and 15. For Action 21, it lists 7, 9, 11,12 and $13 .{ }^{1}$ This is more comprehensive than some of the related policy documents in Ireland that often only state in the introduction that the SDGs need to be taken into consideration. Finally, the most localised climate policy level is that of the Local Authority Climate Adaptation Strategies. In the example of Cork, the most relevant are Actions 22 and 23 respectively:

Establish a procedure for structural integrity assessments of infrastructure after extreme weather events.

Integrate climate considerations into the design, planning, tendering process and construction of all transport infrastructure. (CCC, 2019: 51)

\footnotetext{
${ }^{1}$ Actions 16 and 21 of the Irish Transport Sectoral Climate Change Adaptation Plan collectively list SDGs: 3 - Good Health and Well-Being; 6 - Clean Water and Sanitation; 7 - Affordable and Clean Energy; 8 - Decent Work and Economic Growth; 9 - Industry, Innovation and Infrastructure; 11 - Sustainable Cities and Communities; 12 - Responsible Consumption and Production; 13 Climate Action; 14 - Life Below Water; 15 - Life on Land.
} 
The actions at this administrative level are relatively vague but the document is backed up by national policies. Individual (town) development plans would also reference these national policies on a case-by-case basis.

It should be noted that the example list of actions provided here is not exhaustive. Individual transport projects might refer to the Flood Risk Management Climate Change Sectoral Adaptation Plan, for example. But what this exercise has hopefully demonstrated is that a clear, hierarchical trail of actions can be traced through policies at various administrative levels in Ireland. These are the Emperor's clothes.

\section{Governing Climate Change Action in Ireland}

As mentioned, the Climate Action and Low Carbon Development Act of 2015 gave momentum to Ireland's action on climate change. It also marked the beginning of a concerted effort to organise people for this purpose. Multiple new agencies and institutions were set up, or the remit of existing ones amended. Some standout elements of this governance infrastructure include:

- Establishment of the National Adaptation Steering Committee 'to provide assistance and guidance to the various sectors (including local authorities) in the development of their sectoral/local-level adaptation plans.' (page 20)

- Inclusion of local government representation on the Committee to boost communication between governance layers (Ibid.)

- Establishment of Climate Action Regional Offices (CAROs) to help drive climate action and plan development at regional and local levels, and provide local authority capacity building (based on anticipated overburdening of local authorities)

- Creation of a High Level Climate Action Steering Group with representation from all relevant government departments and agencies. Meets quarterly to drive progress by sectors and agencies to implement the NMP and NAF

- Creation of the Climate Change Advisory Council 'to provide independent advice and to make recommendations to the government and ministers in relation to the low-carbon transition process and the adaptation agenda.' (page 21$)^{*}$ 
- An Adaptation Committee was added to the Climate Change Advisory Council in 2016 with representation from science, local authorities and sectors

The interconnectedness of these groups, councils and committees is as comprehensive as it is complex. The overarching goal of this infrastructure is to ensure that processes and actions do not go uninformed, and that expert advice is integrated at all stages. Citizen and stakeholder input is also sought where possible, such as through the National Dialogue on Climate Action (NDCA). The NDCA aims to create awareness, engagement and motivation to act, and facilitates gatherings for discussions that can influence policy. It also incorporates a range of initiatives including a 'Green Schools' programme, an Environmental Protection Agency (EPA) climate lecture series, and a 'Tidy Towns Climate Action Award'. A Citizens' Assembly on climate change was also organised, which was tasked to consider 'How the State can make Ireland a Leader in tackling Climate Change' (TCA, 2018). Ninety-nine randomly selected Irish citizens were asked to make recommendations on climate action guided by expert advice. Analysis of this process has suggested that citizens' assemblies 'have a significant contribution to make in engaging and communicating with the public more deeply on the climate crisis' (Devaney et al., 2020: 144-145). Interestingly, one hundred percent of the assembly members agreed that the Irish Government should take a strong leadership role in addressing climate change (TCA, 2018). The policies and 'governance architecture' (Biermann et al., 2009) outlined in this section suggest this is indeed happening. However, examples from a small-town case study in Ireland provide evidence of mixed messages from above.

\section{The Town of Youghal, County Cork}

Youghal is a coastal town of almost 9000 people located at the estuary of the River Blackwater, which forms the border to Co. Waterford. The map in Fig. 6.1 shows the south coast of Ireland and the location of Youghal in relation to the cities of Cork and Waterford:

According to the 2018 Community Development Resource Centre Profile report: 


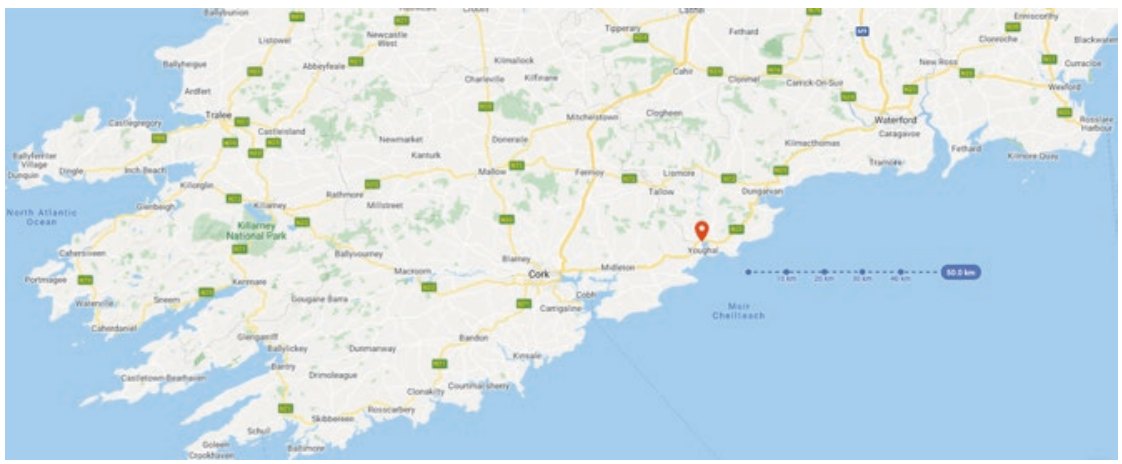

Fig. 6.1 Map showing the location of Youghal in County Cork. (Adapted from Google Maps)

Youghal, taking its name from the Irish word eochaill meaning 'yew wood', is a historic sea-port town on the east coast of County Cork. The Irish Tourist Board has designated it an Irish Heritage Port. In the 19th and earlier 20th centuries, Youghal was one of the busiest sea-ports in the country. The town was also well rooted in the manufacturing industry and had a thriving economy.

In recent times, industry has decreased substantially in the area and tourism is now a main focus. Steeped in the history of Walter Raleigh and Moby Dick, Youghal draws on its heritage, elegantly restored architecture and several well-preserved beaches to attract Irish and international visitors (Cumann Na Daoine, 2018).

This short excerpt presents some of the aspects of modern Youghal most relevant to this chapter. In the 1950s, a booming carpet manufacturing sector was able to support the town. This industry finally subsided in 2003 and anecdotal evidence collected during the BCOMAR project (see Footnote 1) suggests that the 'Celtic Tiger' economic boom between 1997 and 2007 largely bypassed the town. As a result, unemployment rose dramatically and even now stands $4 \%$ above the national average at $11 \%$, while the local deprivation index is at -7.98 , and the average for County Cork is +2.5 (Ibid.). Forty percent of the town is classified as 'disadvantaged' or 'very disadvantaged'. The town also faces climate change-related vulnerabilities. A significant portion of the town centre is 
built on reclaimed land and is very low-lying. When severe storms occur at high tide, coastal flooding and damage affects these areas. This now happens every two years on average and sea level rise is likely to exacerbate the problem.

The excerpt above also hints at the opportunities in Youghal to use natural and cultural heritage assets to attract both domestic and international tourists. Walter Raleigh allegedly planted the first potato in Ireland in the town, and the opening scenes of the original Moby Dick film adaptation were filmed in and around Youghal marina (Huston, 1956). The coastal wetlands to the north and southwest of the town support a variety of bird species. St Mary's Collegiate Church (dating back to the 14th century) and the Clock Gate Tower in the town centre are significant heritage attractions. The town was also chosen to host Ireland's first IronMan triathlons for three years up to and including 2021. In the days leading up to the triathlon, the town's population effectively increases by $25 \%$ and local businesses benefit greatly.

To help realise the potential of these local assets, the Youghal SocioEconomic Development Group (YSEDG) and Daniel Noonan Archaeological Consultancy, in response to a request by Cork County Council, compiled a plan: YOUGHAL - A Heritage-Led Vision to the Next Decade, henceforth 'The Vision'. 'The Vision' was supported by The Heritage Council of Ireland. It is a well-presented document that provides a comprehensive overview of the local heritage assets and how the potential benefit of these might be maximised. It lists a series of enhancement projects, details how these will link together, and how the town will be made more navigable for tourists through directional, interpretative and orientational signposts.

From the perspective of this chapter, however, it is notable that the word 'climate' only appears once in 'The Vision'. It is used to point out that older buildings in the town 'were designed with energy conservation in mind, taking advantage of natural light, cross-ventilation, and climateappropriate materials' (YSEDG, 2019: 45). Reading the document, it is very clear that increasing visitor numbers to Youghal and catering for their needs is the main goal of the authors. They have the right to do this, and to seek ways to alleviate the economic hardships of its recent past. 
However, the connections between local and national aspirations are worthy of scrutiny. Tourism is one of Ireland's leading economic sectors, generating $€ 5.6$ billion in 2018 (from international visitors) and supporting up to 325,000 jobs. ' 'The Vision' fits into wider aspirations set out by Fáilte Ireland, the National Tourism Development Authority, to expand this sector. Fáilte Ireland has led an extremely successful branding campaign for four distinct parts of the country: The Wild Atlantic Way, Ireland's Ancient East, Ireland's Hidden Heartlands and Dublin. Youghal is located in Ireland's Ancient East (IAE). In a 'Path to Growth' document, Fáilte Ireland describes IAE as 'a branded visitor experience encompassing the rich heritage and cultural assets that Ireland has to offer in the midlands/eastern half of the country, providing a counterbalance to the Wild Atlantic Way on the west coast' (Fáilte Ireland). Tourism is supported by an extensive transport, catering and leisure infrastructure. Sustainable management of this infrastructure (and of its growth) is a fundamental climate change challenge, both in terms of mitigation and adaptation. Despite this, the 'Path to Growth' document makes no reference to the climate.

There was another local vision building exercise that the BCOMAR team was able to observe in Youghal. The My Town, My Plan Community Training Programme Initiative ('My Town, My Plan') was set up by the Hincks Centre for Entrepreneurship Excellence at the Cork Institute of Technology (CIT) and worked in collaboration with the South and East Cork Area Development Partnership CLG (SECAD). According to the Hincks website, 'workshops are being used to provide information, stimulate discussion, link resources and develop an action plan in conjunction with the communities in the areas', in order to plan for the future with local residents. The programme ran in eight towns in County Cork. We attended the sessions to observe an example of how a local group might convene to discuss options for developing their town. Debate was open and varied, and well supported by SECAD professionals.

We raised the issue of local climate change vulnerabilities and how these might be integrated into plans to expand on local amenities and attract

\footnotetext{
${ }^{2}$ Irish Government online at: https://www.gov.ie/en/policy/3fcc3a-tourism/. Last accessed 23/07/2020.
} 
tourists. Our team was asked to compile some ideas for doing this. To provide two brief examples, we suggested that the two coastal wetland areas be used in hybrid coastal flood defences (Sutton-Grier et al., 2015), also known as 'building with nature' (Bridges et al., 2015). This is widely accepted as a more sustainable approach than pure 'grey infrastructure' such as sea walls. We also suggested that the eroded groynes be reinstalled on the main beach in Youghal (Front Strand). This could encourage sediment deposition, thus widening the popular beach and also improving coastal flood protection. These ideas could enhance the regulating and cultural ecosystem services provided by these two features (Luisetti et al., 2011). Ultimately, no climate change adaptation measures were included in the final plan, although it did propose the construction of a train line to Cork City, with the hope that this would improve connectivity, whilst reducing traffic congestion and carbon emissions.

\section{Clothing the Emperor}

Youghal cannot be representative of how all of Ireland's coastal towns will react in the face of climate change impacts, but it does demonstrate quite aptly how local, informal governance networks are the first port of call for affecting change. Sports teams, church groups, hobby groups, conservation societies, business associations, etc. help to govern local life. These actors conceive ideas and projects. Regional and national governing bodies (and their policies) come into play at a later stage. But, to a certain extent, towns and villages govern themselves. The Irish Government has set out the clear national governance framework for climate change (outlined above) but has perhaps overlooked the potential of this local governance architecture. This architecture is not an obstacle in implementing change, but a potential asset. It could be mobilised (enticed) to deliver a lot more on climate action. Little effort has been made so far to encourage Youghal to present itself as a town that is adapting to climate change or as a pioneer in surviving rising sea levels. To do so would be remarkably innovative and, according to the World Economic Forum, it is the basis of future job creation (WEF, 2020). 
At present, there is a lack of incentives for towns to develop in this way. Whilst the Irish Government is leading on climate action, it is simultaneously continuing to support actions that are not innately sustainable, non-polluting or adaptive. There is little concerted effort to ensure that the impact drivers for transformational change far outweigh the impact drivers that cause climate change. Tourism is a good example. Tourism is one of Ireland's largest economic sectors and one where climate change factors need to be taken seriously. Yet, 'The Vision' for Youghal does not express a strong intention to do so. Some of the climate change slack will be picked up by planning regulations and incentives when the projects outlined by 'The Vision' are realised, but an opportunity has been missed to present a more comprehensively sustainable approach. This is not the fault of the YSEDG and its partners. They have followed the more enticing national policies (and funding) designed to increase tourist footfall in Ireland. A similar observation can be made of the ideas emerging from the 'My Town, My Plan' process (though less tourism-focused). Again, this is through little fault of the organisers and contributors.

It also shouldn't be assumed that towns and villages govern themselves well. Local projects can be ill-conceived. However, further research might explore the potential for local focus groups to seek 'sustainable pathways', for example (IPCC, 2014). The 'sustainable pathways' concept also features prominently in national climate change policy in Ireland, such as the NAF, but with little guidance provided on implementation. The concept encourages broad input into decision points that support the selection of sustainable future trajectories, based on an understanding of risk, vulnerability and opportunity. The process could be overseen by local 'climate action officers' who would be employed to work full-time on mitigation and adaptation solutions. A similar recommendation was made for repurposing abandoned buildings in Ireland to provide sufficient housing (TCLI, 2020). Providing funding for increased local human resources would be one way for the Irish Government to 'walk the walk' on climate action. Supporting meaningful climate action would also bolster efforts in DRR and achieving the SDGs.

In Hans Christian Andersen's tale, The Emperor's New Clothes, the swindlers who arrive in town and pose as weavers carry evil intent. Their goal is to con the Emperor out of money and lay the blame for all who 
cannot see his clothes on the ineptitude and stupidity of the beholder. There is no suggestion in this chapter that the Irish Government carries evil intent by weaving invisible policies. The Irish Government is elaborately dressed for climate action. But many of its clothes, if not invisible, at the very least have large holes in them. The result is that - from the perspective of climate action - more localised plans and initiatives are free to roam naked.

Acknowledgements This case study information from Youghal is taken from the BCOMAR project - Building Coastal and Marine Resilience: Ireland's Climate Action. The project is due to finish in 2021 and is funded by the Environmental Protection Agency (EPA) and The Marine Institute in Ireland. The project is hosted by Science Foundation Ireland (SFI) Research Centre for Energy, Climate and Marine (MaREI, University College Cork) and the National University of Ireland Galway. Research methods include formal, semistructured interviews, surveys and document analysis.

\section{References}

Andersen, H. C. (1949). The emperor's new clothes. Burton, V. L., \& Houghton Mifflin Company. (1949). (Original published 1837).

Biermann, F., Betsill, M., Gupta, J., Kani, N., Lebel, L., Liverman, D., Schroeder, H., \& Siebenhüner, B. (2009). Earth System Governance: People, Places and the Planet. Science and Implementation Plan of the Earth System Governance Project. IHDP Report No. 20. Bonn.

Bridges, T. S., Burks-Copes, K. A., Bates, M. E., Collier, Z. A., Fischenich, J. C., Piercy, C. D., ... Gailani, J. Z. (2015). Use of Natural and Nature-Based Features (NNBF) for Coastal Resilience. US Army Engineer Research and Development Center, Environmental Laboratory.

Clarke, J., \& Flannery, W. (2020). The Post-Political Nature of Marine Spatial Planning and Modalities for Its Re-Politicisation. Journal of Environmental Policy \& Planning, 22(2), 170-183.

Cork County Council (CCC). (2019). Climate Adaptation Strategy 2019-2024. Available at: https://www.corkcoco.ie/sites/default/files/2019-10/Cork\%20 County\%20Council\%20Climate\%20Adaptation \%20Strategy\%20 2019-2024\%20Final.pdf. Accessed 23 July 2020. 
Cumann Na Daoine. (2018). Cumann Na Daoine (Youghal Community Development Resource Centre). Youghal Community Profile 2018. Available at: https://www.communityconsultants.ie/demo/wp-content/uploads/2018/10/ Youghal-Community-Profile-2018.pdf. Accessed 23 July 2020.

Department for Transport, Tourism and Sport (DTTS). (2019). Sectoral Adaptation Plan for Transport Infrastructure. Available at: https://assets.gov. ie/39222/284b27f3507a411b982d8aff91e1bf49.pdf. Accessed 23 July 2020.

Department of Communications, Climate Action and Environment (DCCAE). (2017). National Mitigation Plan. Available at: https://www.dccae.gov.ie/ documents/National\%20Mitigation\%20Plan\%202017.pdf. Accessed 23 July 2020.

Department of Communications, Climate Action and Environment (DCCAE). (2018). National Adaptation Framework Planning for a Climate Resilient Ireland. Available at: https://www.dccae.gov.ie/documents/National\%20 Adaptation\%20Framework.pdf. Accessed 23 July 2020.

Department of Communications, Climate Action and Environment (DCCAE). (2019). Climate Action Plan 2019 - To Tackle Climate Breakdown. Available at: https://www.dccae.gov.ie/documents/Climate\%20Action\%20Plan\%20 2019.pdf. Accessed 23 July 2020.

Department of Housing Planning and Local Government (DHPLG). (2018). Project Ireland 2040 - National Planning Framework. Available at: https:// www.gov.ie/pdf/?file=https://assets.gov.ie/166/310818095340-ProjectIreland-2040-NPF.pdf\#page=1. Accessed 23 July 2020.

Desmond, M. (2018). National Preparedness to Adapt to Climate Change: Analysis of State of Play (Report No. 256). Environmental Protection Agency. Available at: http://www.epa.ie/pubs/reports/research/climate/Research_Report_256. pdf. Accessed 23 July 2020.

Devaney, L., Torney, D., Brereton, P., \& Coleman, M. (2020). Ireland's Citizens' Assembly on Climate Change: Lessons for Deliberative Public Engagement and Communication. Environmental Communication, 14(2), 141-146.

Di Gregorio, M., Nurrochmat, D. R., Paavola, J., Sari, I. M., Fatorelli, L., Pramova, E., ... Kusumadewi, S. D. (2017). Climate Policy Integration in the Land Use Sector: Mitigation, Adaptation and Sustainable Development Linkages. Environmental Science \& Policy, 67, 35-43.

Fáilte Ireland. Ireland's Ancient East Path to Growth. Five Year Plan for the Development of. Ireland's Ancient East. Our Strategic Intent. Available at: https://www.failteireland.ie/FailteIreland/media/WebsiteStructure/ Documents/2_Develop_Your_Business/Key\%20Projects/Ireland\%27s\%20 
Ancient\%20East/Failte_Ireland_Irelands_Ancient_East_Path_to_Growth_ Strategy.pdf. Accessed 23 July 2020.

Healey, P. (2003). Collaborative Planning in Perspective. Planning Theory, 2(2), 101-123.

Huston, J. (1956). Moby Dick [Film]. Warner Bros.

Intergovernmental Panel on Climate Change (IPCC). (2014). Urban Areas. In Climate Change 2014: Impacts, Adaptations and Vulnerability. Contribution of Working Group II to the Fifth Assessment Report of the Intergovernmental Panel on Climate Change. IPCC.

Irish-Government. (2018). National Development Plan 2018-2027. Available at: https://www.gov.ie/pdf/?file=https://assets.gov.ie/37937/12baa8fe0dcb4 3a78122fb316dc51277.pdf\#page=null. Accessed 23 July 2020.

Kjaer, A. M. (2004). Governance: Key Concepts. Polity Press.

Kjellstrom, T., \& McMichael, A. J. (2013). Climate Change Threats to Population Health and Well-Being: The Imperative of Protective Solutions That Will Last. Global Health Action, 6(1), 20816.

Luisetti, T., Turner, R. K., Bateman, I. J., Morse-Jones, S., Adams, C., \& Fonseca, L. (2011). Coastal and Marine Ecosystem Services Valuation for Policy and Management: Managed Realignment Case Studies in England. Ocean \& Coastal Management, 54(3), 212-224. https://doi.org/10.1016/j. ocecoaman.2010.11.003

Morrison, T. H., Adger, W. N., Brown, K., Lemos, M. C., Huitema, D., \& Hughes, T. P. (2017). Mitigation and Adaptation in Polycentric Systems: Sources of Power in the Pursuit of Collective Goals. Wiley Interdisciplinary Reviews: Climate Change, 8(5), e479.

Nabi, R. L., Gustafson, A., \& Jensen, R. (2018). Framing Climate Change: Exploring the Role of Emotion in Generating Advocacy Behavior. Science Communication, 40(4), 442-468.

O'Neill, S., \& Nicholson-Cole, S. (2009). "Fear Won't Do It" Promoting Positive Engagement with Climate Change Through Visual and Iconic Representations. Science Communication, 30(3), 355-379.

Smith, G., \& Jentoft, S. (2017). Marine Spatial Planning in Scotland. Levelling the Playing Field? Marine Policy, 84, 33-41.

Sutton-Grier, A. E., Wowk, K., \& Bamford, H. (2015). Future of Our Coasts: The Potential for Natural and Hybrid Infrastructure to Enhance the Resilience of Our Coastal Communities, Economies and Ecosystems. Environmental Science \& Policy, 51, 137-148. 
Tafon, R. V. (2018). Taking Power to Sea: Towards a Post-Structuralist Discourse Theoretical Critique of Marine Spatial Planning. Environment and Planning C: Politics and Space, 36(2), 258-273.

The Citizens' Assembly (TCA). (2018). Third Report and Recommendations:

How the State Can Make Ireland a Leader in Tackling Climate Change.

The Town Centre Living Initiative (TCLI). (2020, May). Six Pilot Towns:

Synthesis Report. Available at: https://www.gov.ie/en/publication/86215the-town-centre-living-initiative/. Accessed 22 July 2020.

Thornton, T. F., \& Comberti, C. (2017). Synergies and Trade-Offs Between Adaptation, Mitigation and Development. Climatic Change, 140(1), 5-18. Thuiller, W., Lavorel, S., Araújo, M. B., Sykes, M. T., \& Prentice, I. C. (2005). Climate Change Threats to Plant Diversity in Europe. Proceedings of the National Academy of Sciences, 102(23), 8245-8250.

Uitto, J. I., Puri, J., \& Van den Berg, R. D. (2017). Evaluating Climate Change Action for Sustainable Development. Springer Nature.

Van Driesche, J., \& Lane, M. (2002). Conservation Through Conversation: Collaborative Planning for Reuse of a Former Military Property in Sauk County, Wisconsin, USA. Planning Theory \& Practice, 3(2), 133-153.

van Kersbergen, K., \& van Waarden, F. (2004). 'Governance' as a Bridge Between Disciplines: Cross-Disciplinary Inspiration Regarding Shifts in Governance and Problems of Governability, Accountability and Legitimacy. European Journal of Political Research, 43(2), 143-171.

World Economic Forum (WEF). (2020). New Nature Economy Report II. The Future of Nature and Business. In Collaboration with AlphaBeta. Available at: https://www.weforum.org/reports/new-nature-economy-report-ii-thefuture-of-nature-and-business. Accessed 23 July 2020.

Youghal Socio-Economic Development Group (YSEDG). (2019). Youghal - A Heritage-Led Vision to the Next Decade. Available at: https://www.heritagecouncil.ie/content/files/Youghal_A_Heritage_Led_-Vision_-to_-the_-Next_ Decade.pdf. Accessed 23 July 2020. 
Open Access This chapter is licensed under the terms of the Creative Commons Attribution 4.0 International License (http://creativecommons.org/ licenses/by/4.0/), which permits use, sharing, adaptation, distribution and reproduction in any medium or format, as long as you give appropriate credit to the original author(s) and the source, provide a link to the Creative Commons licence and indicate if changes were made.

The images or other third party material in this chapter are included in the chapter's Creative Commons licence, unless indicated otherwise in a credit line to the material. If material is not included in the chapter's Creative Commons licence and your intended use is not permitted by statutory regulation or exceeds the permitted use, you will need to obtain permission directly from the copyright holder.

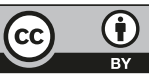

